\title{
Restructuring NDDC: Pathway to Development in the Niger Delta Region
}

\author{
Kingsley Ubiebi \& Ikechukwu Stanley Ogbonna \\ http://dx.doi./org/10.4314/ujah.v21i4.16
}

\begin{abstract}
Niger Delta comprises of the South-South states, Ondo state from the South west, Imo and Abia States from the South East region of Nigeria. Despite the huge mineral resources that the region generates and the driving force to the national economy, the region remains in abject poverty, youth unemployment, poor infrastructure and high level insecurity. This paper investigates the role of NDDC, successes and challenges in the development of Niger Delta region. The Marxist instrumentalist theory was adopted as the theoretical framework of analysis. Documentary method was adopted as the method of data collection and content analysis was employed as the method of analysis. The paper found out that the federal government has created several interventionist bodies which include the Niger Delta Development Board (NDDB) (1958), the Oil Minerals Producing and Development Commission (OMPADEC) (1992), the Niger Delta Development Commission (NDDC) (2000) and the most recent, Ministry of Niger Delta (2008). In spite of this various interventionist bodies, the region is still far underdeveloped with little or nothing on ground compared to what is being exploited from the region. As an oil producing region, it ought to enjoy massive infrastructural development, job creation, empowerment programs and peaceful society, among others. However, this paper is of the view that a lot still needs to be done, as the region is retrogressing speedily instead of progressing in regards to the core indices of development. This paper also found out that corruption has eaten deep into the affair of NDDC. There is also a report of a cabal who hijacks contracts and
\end{abstract}


sells it to contractors that end up doing low standard jobs not in line with the bill of quantities or not doing at all. The paper recommends total restructuring of Ministry of Niger Delta and NDDC in area of staff posting and review of organogram of the board. There should be a think-tank team of individuals with reputable character both from government and representatives of the people, towards listing out the needs of the people according to preference. A review of projects done and the ones ongoing across the Niger Delta oil producing states with the contractors involved to see if it is in line with the bill of quantities, any contractor found wanting should face the full wrath of the law.

Keywords: Restructuring, Development, Niger Delta, Corruption, Oil Politics

\section{Introduction}

Nigeria is at crossroad and there is agitation from different parts of the country to reform the nation. Niger Delta region is among those clamoring for restructuring in Nigeria, not just political restructuring, but development restructuring as it affects the region. Niger Delta is blessed with oil and gas, these natural resources has survived the Nigeria economy for over four decades and still counting. Despite the contributions to the centre by the region, the region has witnessed high level of environmental pollutions, gross underdevelopment, lack of access to basic infrastructure, quality education, poor health services and massive political marginalization; the dependency of oil by over 200 million Nigerians with little or no tangible development to show for in the Niger Delta, is a major contributory factor to the present ethnic perturbation from the region (Patrick, Offiong and Enemuo, 2012; Hart, 2016).

However, the practice of federalism has been on ground in Nigeria over decades now, the clamoring for restructuring in order to 
have control and what some scholars called "true federalism" is not new in the Nigeria history (Agwanwo, 2014; Anugwan, 2005; Awofeso, 2017; Babalola, 2015; Chijioke, Innocent \& Emeh, 2012; Elekwa et al, 2011; Madubuike, 2015; Ojakorotu, 2008). Therefore, it is not new, from current issues; that there are calls by certain parts of the country. It is a known fact, that some regions are dissatisfied with the central government of the day. Putting into consideration, that the central government and other regions solely rely on revenue allocation from the federation account with huge percentage coming from the oil revenues (Niger Delta) ( Agwanwo, 2014; Anugwan, 2005; Awofeso, 2017; Chijioke et al, 2012; Elekwa et al, 2011; Madubuike, 2017; Ojakorotu, 2008).

Scholars and analysts such as, ( Patrick et al, 2012; Agwanwo, 2014; Anugwan, 2005; Awofeso, 2017; Babalola, 2015; Chijoke et al, 2012; Elekwa et al, 2011; Madubuike, 2015; Ojakorotu, 2008) have discussed several issues on marginalization of the Niger Delta region, resource control, revenue allocation, insecurity, abject poverty and insecurity in the Niger Delta region. However, known have looked into the restructuring of the interventionist bodies that do manage the affairs of the region and the central government that are in charge of the appointment of individuals that run the day to day activities of the region, especially high level of corruption have rarely been the subject of systematic intellectual enquiry.

This paper investigates the role of interventionist bodies, successes and challenges in the development of the Niger Delta.

\section{Theoretical Framework}

This study is solemn relied on the "Marxist instrumentalist theory". The Marxist instrumentalist theory was promoted by Ralph Miliband and William Domhoff (cited in McGowan \& Walker 1981). The main base of the Marxist instrumentalist theory is that the state majorly drives the interest of the elite class simply based on the fact that the 
state is majorly controlled by the elite class. This means, as against the general assumption that the state is unbiased and neutral power broker in relation to the interest of capital and labour, the state is a capitalist society basically functions to uphold and defend capitalist accumulation and profit in the society (Asobie, 1990).

Basically, William Domoff who examined policy formation from an instrumentalist paradigm was able to establish certain distinctive process through which the capitalist class is able to use the state as an instrument at will to shape policy in its interest. These processes include the special-interest process, the policy-planning process, among others. In this light, McGowan and Walker (1981) sustain the opinion that the special interest process has to do with lobbying the decision makers by interest groups, especially the powerful capitalist class to adopt specific policies and general development blueprint that broadened their interest or to circumvent policies and development plans that compromises their interest. McGowan and Walker (1981) further establish that policy planning permits the capitalist class to promote, protect and rationalize a particular way of examining reality through the introduction and identification of specific personnel and ideas.

The fulcrum of Marxian instrumentalist analysis rests on the production and distribution process in the society. In essence, the theorist believes that the capitalist class necessarily employs the apparatuses of the state to advance its collective interest. Hence, the central argument of Marxian instrumentalist theory is that the state pursues the interest of the ruling class in capitalist society rather than the interest of the other social assembles due to the direct involvement of members of the ruling class in the state machineries and economic processes. Marxian instrumentalist theory, therefore, draws attention to the connections between members of the ruling class and the key actors in the policy making institutions of government in order to highlight that the state lacks independence or initiatory role, since its 
power is entirely rooted in the economy that is dominated and controlled by the ruling class.

Application to theory, linked to restructuring: pathway to development in the Niger Delta region, the capitalist class through their special interest process and policy-planning process has shortchanged the Niger Delta in terms of the interest and introduction of interventionist bodies as it affects the Niger Delta region. However, the interventionist bodies have brought relative peace to the Niger Delta i.e, NDDB, OMPADEC, NDDC and Ministry of Niger Delta Affairs but in return, development is farfetched to the Niger Delta as an oil producing region that produce the goose that lay the golden egg.

Furthermore, the various individuals and management team set up by the federal government has not coordinated the affairs of the bodies according to the set goals, instead it has been for enrichment of their interest and cronies from state to federal levels leaving the masses in pains with little or nothing to show compared to the allocation received on a yearly basis.

\section{Conceptual clarification}

Restructuring: According to Obiora (2018), restructuring can simply be seen as a process to re-strategize an existing order to a more reliable one that is beneficial to the people. From the above definition, restructuring is a target driven process that is centered on replacing an existing order to a more reliable and purpose driven in order to achieve a set goal. In view of the above, restructuring is centered on re-organization, reformation and re-arrangement of an established structure or status quo to form a more robust and functional system that will meet the pressing needs of the people or an organization.

Development: According to Mier (1988), development is the process of growing to the highest value of the Gross National Product through 
the process of securing capital and industrialization. Development can also be seen as the capacity of a nation to increase its stagnant economy to a more favorable economy in rapid growth in its Gross national Product (GNP) that is sustainable to the people's needs. In addition, Oghator \& Okobo (2000) sees development beyond the rise in per-capita income or economic growth, but the sustainable improvements of the living standard of the people, in regards to social and economic infrastructures, job creation, security and empowerment prorammes that will enable them live a fulfilled life.

Furthermore, Ajagun (2003) justifies that development is a state of progress which makes life more meaningful in its various aspects, including the economic, administrative, political, social, cultural and religious aspects. This implies that development is not about a particular aspect but it is encompassing, better still multidimensional depending on the point of contention.

Niger Delta: Niger Delta is organized politico-administratively into nine of the currently thirty six states of the federation. These states are Abia, Akwa-Ibom, Bayelsa, Cross River, Delta, Edo, Imo, Ondo and Rivers. The Niger Delta is reputed to be the third largest wetland in the world, which sustains a complex biodiversity, otherwise attractive to tourists, explorers, adventures, traders, business men and women, academics and a variety of researchers. According to Otite (2009), the area called the Niger Delta is characterized by ethnic pluralism as inhabited by Andoni, Bekwara, Bini, Efik, Egbema, Ekoi, Ibibio, Igbo, Ijaw, Isoko, Itsekiri, Ogoni, Urhobo and several others.

The Niger Delta region in Nigeria extends over about $70,000 \mathrm{~km} 2$ and makes up about 75 of Nigerian land mass. It consists presently of nine (9) states namely, Rivers, Cross River, Akwa Ibom, Imo, Delta, Edo, Ondo, Abia and Bayelsa. The region has a population of 30 million people in 2006 which is about 23 percent of the total Nigerian population of 140 million. The people of the region 
rely mainly on farming and fishing as their major source of livelihood (SaroWiwa, 1998). Niger Delta Region is the geographical heart of crude oil exploration in Nigeria from where the nation earns up to 99.7 and 90 percent of its export and annual income respectively (IMF, 2003; Azaiki, 2007).

Corruption: According to Salisu (2000), corruption is that it is the misapplication of public resources to private ends. For example, public Officials may collect bribes for issuing Passports or Visa, for providing goods at sea/airport for awarding contracts or artificial scarcity. Konie (2003), identified two types of corruption, these are, Vertical corruption, which involves managers and decision makers. This is common in less developed countries and; Horizontal corruption, which involves the entire Officials, informed and laymen groups in the countries. The two types of corruption should be seriously addressed and eradicated if any meaningful economic or political progress is to be made. Corruption also reduces economic growth, enhances inequalities and reduces the government's capacity to respond to people's needs. Corruption leads to a grooving gap between the rich and the poor and deepens poverty by enriching a few at the expense of fellow citizens. Under a corrupt system, there is a concentration of wealth in the hands of a tiny minority of the population. Resultantly income distribution becomes highly skewed.

\section{Methodology}

This subject of this paper has necessitated documentary method of data collection. This invariably attracts content analysis of secondary data, drawn from books, journals, news papers and internet sources as herein used. 


\section{The Niger Delta Region and Underdevelopment}

After decades of military rule in Nigeria, Nigeria returned to civilian rule in 1999, which gives ethnic minority in the Niger Delta relevance to clamour for a more favorable distribution of oil wealth which the region is the highest producer till date. Geographically, the Niger Delta is made up of 9 states, 6 states from the south south (Bayelsa, Rivers, Akwa-Ibom, Cross River, Edo and Delta), 2 states from southeast (Abia and Imo) and 1 state from south west (Ondo) (NDDC, 2004; UNDP, 2006: 19; www.nddconline.org). The aforementioned states are the main oil-producing states

The Niger Delta people, are not clamouring for restructuring due increase of revenue allocation formula, but based on total neglect of the region with special reference to abject poverty, lack of infrastructural development, unemployment, appointment, among others too numerous to mention. Putting into consideration, that Niger Delta region is the producers of the entire federation's wealth that sustained the Nigeria state till date. More so, Niger Delta region has suffered harsh oil exploration which has resulted monumental environmental degradation and in turn, affected the economic life of the people who are majorly engaged in farming and fishing for livelihood. Also, the locals who lose their farmland to oil spills are mostly not compensated. (Ejobowah, 2000; Frynas, 2000; Manby, 1999; Obi, 2006; UNDP, 2006; Welch, 1995).

Accordingly, the United Nations Development Programme (UNDP), in a blunt description of the level of underdevelopment in the Niger Delta region, carefully observed that the expectations of the people are falling despite the increase of oil prices. The availability of energy is close to nothing, putting into consideration of a region that provides one-fifth of the energy needs of the United States. Lack of roads in a region whose wealth funds massive infrastructural development in other parts of Nigeria and expensive peacekeeping activities in other parts of Africa (UNDP, 2006:25). 


\section{Oil Politics and the Clamour for Restructuring in Nigeria}

The discovery of oil in Nigeria has influenced the structure of the political economy of Nigeria (Clark 2016). Clark argued that the temporary stay of military in Nigeria politics and the notorious character of the ruling elites open the cankerworms of cash from the oil industry. For example, true federalism that was expected to deliver rapid development in Nigeria, most importantly in the Niger Delta where massive development is needed, have been abandoned by the ruling elites and the military (Clark, 2016). In Clark words, he stated:

For interest sake, powerful political groups initiated different formulae to enable them be in control of the oil wealth in the regions/ states and also the huge petrodollars for their Pocket sake. In addendum, the 50 percent derivation to receive by states/ regions as intro-duce by the 1963 republican constitution was cancelled by the intervention of military in Politics (Clark, 2016, p.76).

According to Eghweree (2014), the agitation for oil resource in Nigeria has brought massive disunity in Nigeria between ethnic nationalities and also created an avenue for politicians to put their interest first before the masses. The discovery of oil made the minority (Niger Delta) who owns the oil to be oppressed by the majority who controls at the centre. Citing Ikelegbe (2005) and Obi (2010), Eghweree (2014) stated thus:

In Nigeria, the control of oil; is the control of power; and the control of power; is the control of the centre who dictate, who get what, when and how (Eghweree, 2014, p.76).

The call for restructuring in the Niger Delta who felt marginalized is due to oil politics (Eghweree 2014). It must be noted, that the call of restructuring has been on ground even before 1999 (Babalola 2014). In a bid to further advocate the call for restructuring, efforts were doubled in 1999 after decades of military dictatorship (Babalola 
2014). Citing UNDP (2006) and NDDC (2004), Babalola listed the following as the Niger Delta States: Abia, Akwa Ibom, Bayelsa, Cross River, Delta, Edo and Rivers are in the South-south. Abia and Imo in the Southeast, Ondo in the South-west (Babalola, 2014). A while ago, Lagos discovered oil and certified as an oil producing state, with ondo state, making it two states in the southwest. The essence of the aforementioned geographical breakdown is to carefully explicit the motive behind the agitation and wide spread across Nigeria state in regards to oil discovery and ownership. Another pivotal issue in regards to true federalism in Nigeria is the issue of sustainability. Having abundant oil reserve in a state is not enough reason to be independent economically for sustainability in all areas of life.

Adetoye, Oweoeye and Omilusi (2017) in an unpublished research paper, argue that the call for fiscal federalism and creation of new state (s) in Nigeria is overemphasized, because state (s) lack adequate readiness to effectively manage their state(s) for productivity and service delivery to the masses. Putting into consideration of the high level of corruption witnessed thus far in the various interventionist bodies from NDDB, OMPADEC, NDDC and Ministry of Niger Delta, none have been able to achieve the major reason why the interventionist bodies were set up, instead it has been massive accumulation of wealth for self aggrandizement and leaving the people in abject poverty, gross unemployment, inadequate road, health care centres among others.

\section{Development of the Niger Delta}

The Niger Delta region of Nigeria is a very vital area to the country. The indispensability of the region is based on its economic value to the nation. One central issue for which Niger Delta remains restive is the deficient level of development that Niger Delta has. Issues of kidnapping and vandalism of oil channels, illegal possession of arms, 
threat to life and general insecurity, experienced in the region, can be traced to the unmet expectation of high level of development, in terms of human capacity by the federal government of Nigeria. Poor infrastructure, undeveloped human resources, damage of natural environment, aquatic destruction due the activities of oil exploration firms, and generally high exposure to controllable but neglected diseases and illnesses, majorly arising from the economic activity of oil exploration in the area, are some of the obvious reasons.

The objective reality of the above issues in the Niger Delta region is known to the government, private individuals and the international community. The concerned quest for a solution to these problems has attracted the attention of capable individual, foreign agencies, non-governmental bodies and the federal government of Nigeria chiefly. The central quest remains a workable idea that could serve as a sustainable panacea to the development challenges of the people of Niger Delta.

Prior to Nigeria's independence in 1960, Niger Delta had attracted colonial intervention. The report of Sir Henry Willink in 1958 projected the infrastructural deficiency of the Niger Delta and gave recommendations to the development challenges of the area. Emmanuel (2017) stated that fifty (50) years after the commission submitted its recommendations; the Niger Delta is yet to witness the much-needed peace and development level as recommended.

This paper does not in any case justify the seeming negligence, under-attention, irresponsiveness and or any form of indifference on the part of the state, from colonial to indigenous administration towards the Niger Delta. However, it is instructive to scientifically state that when an objective study such as this concentrates on the Niger Delta, one begins to ask: why has the Niger Delta development, in spite of the numerous efforts made been repulsive to treatments? What is the justification for the stubborn 
sameness of the Niger Delta development, irrespective of the unique focus seen in multiple billions of the hard and foreign currencies pumped into the region by the Nigerian government and so many other foreign bodies, private individual and NGOs? On an objective basis, is the state to be blamed generally, or is there the need to scrutinize the activities of the numerous state interventionist institutions such as the Niger Delta Development Board (NDDB), the Niger Delta River Basin Development Authority (NDRBDA), Presidential Tax Force on Niger Delta Development (PTFNDD), Oil Mineral Producing Area Development Commission(OMPADEC), Niger Delta Development Commission, (NDDC) and the Ministry of Niger Delta Affairs (MNDA), mandated by various administrations to champion the course of development in the Niger delta? These questions gave rise to this study as a matter of necessity.

The Niger Delta Development Board (NDDB), was founded in 1960 based on the 1958 Willink Commission's recommendations. The board according to Paul Deirdre, Lapin and Paul Rossiasco (2011), had colonial government contributions and carried out the policy of the colonial government by focusing mainly on agricultural development. The NDDB in 1960, was affected by political crisis and civil war. The Murtala/Obasanjo military administration in 1976, established the Niger Delta River Basin Development Authority (NDRBDA). The NDRBDA, likewise its predecessors achieved less for the Niger Delta. The Murtala/Obasanjo administration was succeeded in 1979 by the Shagari/Ekueme civilian administration.

In 1982, the Shehu Shagari administration set up a Presidential Task Force on Niger Delta Development (PTFNDD). The PTFNDD was charged likewise with the responsibility of formulating viable solution to the development problem of the Niger Delta. The PTFNDD was however had moderate fund and was noted for little development impacts. The President Ibrahim Badamusi Babangida 
administration, in 1993, established the Oil Mineral Producing Area Development Commission (OMPADEC). Paul Francis Deirdre, LaPin, Paula Rossiasco (2011), observed that despite the financial generosity in the statutory allocation of 3 percent derivation, OMPADEC was noted for poor planning and poor consultation with constituents of the Niger Delta, abandoned projects and corruption in the officials of the commission, among others. It is essential to note that failure of OMPADEC to give a substantive value justification vis-à-vis the huge oil derivation funding resulted in rising anger in the region.

The last two military administrations to the currently sustainable democracy in Nigeria had no notable focus in solving the problem of the development of the Niger Delta. The Abacha Administration received global condemnation for the killing of the Niger Delta civil activist - Ken Saro Wiwa in 1995, over the course of the development of the Niger Delta. At the death of Abacha in 1998, the successive administration of General Abdulsalami Abubakar, had less time in office for other national issues, other than the project of returning Nigeria to democracy in 1999.

At the nation's return to democracy on May $29^{\text {th }}, 1999$, the quest for a lasting solution to the problem of development of the Niger Delta continued. Angela Ajodo A. (2017) and A.J. Falode (2013), observed that the Olusegun Obasanjo administration in 2001, established the Niger Delta Development Commission (NDDC). The aim of the commission was to:

"conceive, plan and implement projects and programs for the sustainable development of the Niger Delta region in the areas of transportation, including roads, jetties, and waterways, health, education, employment, industrialization, agriculture and fisheries, housing and urban development, water supply, electricity and telecommunications." (NDDC Act section 7(1) (b)) cited in Paul F.et al (2011). 
The following table shows the various interventionist bodies established for the development of the Niger Delta region:

\begin{tabular}{|l|l|l|l|}
\hline $\begin{array}{l}\text { Interventionist } \\
\text { Bodies }\end{array}$ & Purpose & Administration & $\begin{array}{l}\text { Year } \\
\text { Created }\end{array}$ \\
\hline NDDB & $\begin{array}{l}\text { Minority peace } \\
\text { \& Niger Delta } \\
\text { Development }\end{array}$ & $\begin{array}{l}\text { Colonial } \\
\text { (1958 Willink } \\
\text { Commission) }\end{array}$ & 1960 \\
\hline NDRBDA & $\begin{array}{l}\text { Niger Delta } \\
\text { Development }\end{array}$ & Murtala/Obasanjo & 1976 \\
\hline PTFNDD & $\begin{array}{l}\text { Niger Delta } \\
\text { Development }\end{array}$ & Shagari/Ekwueme & 1982 \\
\hline OMPADEC & $\begin{array}{l}\text { Niger Delta } \\
\text { Development }\end{array}$ & Ibrahim Babangida & 1993 \\
\hline NDDC & $\begin{array}{l}\text { Niger Delta } \\
\text { Development }\end{array}$ & Olusegun Obasanjo & 1999 \\
\hline MNDA & $\begin{array}{l}\text { Niger Delta } \\
\text { Development }\end{array}$ & $\begin{array}{l}\text { Shehu Musa } \\
\text { Yar'Adua }\end{array}$ & $\begin{array}{l}\text { 2008 } \\
\text { (still in } \\
\text { existence at } \\
\text { the time of } \\
\text { this report) }\end{array}$ \\
\hline
\end{tabular}

Source: Authors' compilation

The financing of the NDDC was as follows:

$15 \%$ of monthly statutory allocation due to the oil producing states, $3 \%$ of the operating budget of the oil and gas producing companies,50\% of the ecological fund due to the Niger Delta States, Foreign aids and private sector contribution. The NDDC funding is pictured in the following table: 
Ubiebi \& Ogbonna: Restructuring NDDC: Pathway to Development in the Niger Delta Region

\begin{tabular}{|l|l|l|l|l|}
\hline Funding Source & $\begin{array}{l}\text { Fund } \\
\text { percentage }\end{array}$ & Amount & Year & $\begin{array}{l}\text { Fund } \\
\text { receiver }\end{array}$ \\
\hline $\begin{array}{l}\text { Monthly allocation } \\
\text { from the FGN }\end{array}$ & 15 & Unstated & & NDDC \\
\hline $\begin{array}{l}\text { Oil and gas } \\
\text { company operating } \\
\text { budget }\end{array}$ & 3 & Unstated & & NDDC \\
\hline $\begin{array}{l}\text { Foreign aid/private } \\
\text { sector }\end{array}$ & Unstated & Unstated & & NDDC \\
\hline $\begin{array}{l}\text { FGN Allocation } \\
\text { (Jonathan) }\end{array}$ & Unstated & $\$ 1.57 \mathrm{bn}$ & 2010 & NDDC \\
\hline $\begin{array}{l}\text { FGN Allocation } \\
\text { (Jonathan) }\end{array}$ & $\$ 3.74 \mathrm{bn}$ & 2011 & NDDC \\
\hline $\begin{array}{l}\text { FGN Allocation } \\
\text { (Buhari) }\end{array}$ & N71.2b & 2018 & NDDC \\
\hline
\end{tabular}

Source: Authors' compilation

In spite of the huge sums of money available to the NDDC, the commission claimed to be underfunded. The NDDC only tried to augment its failure in ensuring development of the Niger Delta, by engaging youth in skill acquisition and scholarship, micro credit for businesses and some other technical social services for the people of the area. It is instructive to note the following lapses about the NDDC as similar to its predecessor interventionist institutions in the Niger Delta:

1. Administrative lack of transparency and accountability

2. Consultation failure with target beneficiaries

3. Proven cases of managerial corruption as seen in the misappropriation of $\$ 5.3 \mathrm{~m}$

4. Uncompleted projects, among others

According to a Radio Nigeria 7 o'clock Network News broadcast of Sunday, November 3, 2019, President Muhammadu Buhari has 
decided to probe the financial activities of the NDDC since 2001 due to rising cased of fund misappropriation. Corroborating this, Aborisade S. (2019) in a Punch News Paper article published on Saturday $2^{\text {nd }}$ of November, 2019 revealed as follows:

The National Assembly has decided to probe the financial transactions of the Niger Delta Development Commission since 2015. President Muhammadu Buhari has since ordered a forensic probe into the agency's accounts and activities while the Senate Committee on Public Accounts is investigating the alleged N1.9bn water hyacinth project scam in the commission. The Chairman, Senate Committee on the NDDC, Peter Nwaoboshi, and his counterpart in the House of Representatives, Olubunmi Tunji-Ojo, in separate interviews with our correspondent said they would conduct separate probes into the affairs of the NDDC. The duo welcomed the forensic audit of the commission ordered by Buhari, but maintained that the exercise would not stop both chambers of the National Assembly from doing the same.

Nwaoboshi said:

The National Assembly, especially the Senate, will do our own full investigation into the activities of the NDDC. Notwithstanding what the executive arm of government is doing about it, we have resolved also to do our own audit. In the 8th National Assembly, we carried out an oversight and during the process, we discovered that many contractors had abandoned their jobs and absconded from the sites after they had collected funds for mobilization. Such situations cannot help the agency. Nwaoboshi, who represents Delta North, also said the committee would look into the alleged misappropriation of funds in the agency. There are other issues that we have discovered. For example, we heard 
of emergency jobs. Such jobs are supposed to be necessary but cannot wait for the completion of the budgeting process. Such jobs have to be done immediately in the general interest of the people. There are so many things that we have seen in the NDDC budget, particularly findings from emergency jobs done. We will review all of them when we finish our investigation. There is also the issue of delisting. It is another avenue for hiding figures. The Senate Committee on Public Accounts is conducting investigation and we are going to do our own because we have more facts than them. We are going to investigate the NDDC thoroughly. There is a case of water hyacinth project, which companies were paid about N1.9bn to clear the hyacinths. We are going to investigate it too. We have been compiling details. Tunji-Ojo, who is the Chairman, House of Representatives Committee on the NDDC, said his panel would from next week, commence investigation into the affairs of the agency. He said, "We will soon start a comprehensive investigation into the affairs and activities of the NDDC in the last three or four years. It will be a holistic probe. We will look at delisting, emergency projects, water hyacinth issue, their budget implementation, adherence to financial regulations and due process. We will also look at the procurement process, budgeting procedure, implementation and framework. We will look at their audited accounts and carry out our own audit. We will look at the various projects awarded to see if they were actually spending taxpayers' money judiciously. We are already working behind the scenes and putting our work plans together so that within the next one or two weeks, we will come out with our plans. We welcome what the executive arm of government is doing about it but we also have the power of oversight since we 
appropriated the funds they were spending on projects and other things to them. - (Punch 2, November 2019)

The following show the budgetary allocation of the Ministry of Niger Delta Affairs (MNDA) 2009-2020:

\begin{tabular}{|l|l|l|l|l|}
\hline S/N & Ministry & $\begin{array}{l}\text { Budgetary } \\
\text { Allocation }\end{array}$ & Year & Administration \\
\hline 1 & NDDC & $\$ 333 \mathrm{M}$ & 2009 & Yar’ Adua \\
\hline 2 & NDDC & $\$ 430 \mathrm{M}$ & 2010 & Yar' Adua \\
\hline 3 & NDDC & $\$ 333 \mathrm{M}$ & 2011 & Goodluck Jonathan \\
\hline 4 & NDDC & N59,534,310,110 & 2012 & Goodluck Jonathan \\
\hline 5 & NDDC & N67.7bn & 2013 & Goodluck Jonathan \\
\hline 6 & NDDC & N111bn & 2014 & Goodluck Jonathan \\
\hline 7 & NDDC & 4.5 tr & 2015 & Goodluck Jonathan \\
\hline 8 & NDDC & N9.440bn & 2016 & Buhari \\
\hline 9 & NDDC & N33bn & 2017 & Buhari \\
\hline 10 & NDDC & N53.89bn & 2018 & Buhari \\
\hline 11 & NDDC & N39.40bn & 2019 & Buhari \\
\hline 12 & NDDC & N24bn & 2020 & Buhari \\
\hline
\end{tabular}

Source: Authors' Compilation

\section{Pursuing Peace and Development in the Niger Delta: The Yar'Adua Amnesty Grant, 2009}

The late President Umaru Musa Yar'Adua administration in 2009 granted amnesty to the people of the Niger Delta region. The idea of the amnesty grant was based on the incessant cases of violent destruction of oil pipelines, kidnapping of multinational workers among others, in the quest for distributive justice in the allocation of the proceeds from oil explored in the area. Oscar E.(2013) noted that the late President Umaru Musa Yar'Adua allocated the sum of 
127bn between 2009 and 2011 for the execution of the amnesty. The table below pictures the utilization of the amnesty fund:

\begin{tabular}{|l|l|l|l|}
\hline S/N & $\begin{array}{l}\text { Amount } \\
\text { Budgeted (N) }\end{array}$ & Administration & Purpose \\
\hline 2009 & $3 \mathrm{bn}$ & Yar' Adua & Program takeoff \\
\hline 2010 & $30 \mathrm{bn}$ & Yar' Adua & $\begin{array}{l}\text { Feeding, stepends and } \\
\text { re-integration of ex- } \\
\text { militants }\end{array}$ \\
\hline 2011 & $90 \mathrm{bn}$ & Goodluck & $\begin{array}{l}\text { Feeding, stipends and } \\
\text { re-integration of ex- } \\
\text { militants }\end{array}$ \\
\hline
\end{tabular}

Source: Oscar E. (2013), modified by the authors

\section{MNDA, NDDC and the Niger Deltans}

Currently, the two institutional systems through which the Nigerian state sustains interventionist interface with the people of Niger Delta region, are the Niger Delta Development Commission (NDDC) and the Ministry of Niger Delta Affairs, (MNDA). The former operates under the later as a parastatal.

Constituents of the Niger Delta region have expressed lack of confidence in managerial character of the officials of the two institutions, seen in corruption, politicization of the institutions, favouritism among others. The reality of the ills in the management of the MNDA and the NDDC beclouds the interventionist manifestation of the efforts of the Federal Government of Nigeria to bring a lasting solution to the development problem of the Niger Delta region. Paul F. et al (2011) note that popular frustration has been expressed through violence by the Niger Delta people. A case in point is the vandalization of the NDDC office in Warri in 2004, by a group of the Ijaw youths protesting the marginalization of their communities. Some prominent leaders in the area viewed the institution of MNDA and the NDDC as simply "private estates." Paul F. et al(2011)n stated 
that the Movement for the Emancipation of the Niger Delta (MEND),in 2016 claimed responsibility for the bomb detonated near the NDDC headquarters in Port Harcourt, and charged the managing direct with acts described as against the interest of the Niger Deltans.

\section{Findings}

In the course of our detailed enquiry into the operations of the NDDC, OMPADEC, NDRBDA, PTFNDD, and the MNDA, the study revealed the following among many others:

1. The federal government of Nigeria has from the colonial era, given development attention to the Niger Delta region.

2. The various interventionist institutions have had the common feature of lack of transparency and accountability.

3. The persistent restiveness of the Niger Delta is traceable to the failure of the interventionist structures to justify their mandate and responsibility of their offices to serve the people vis-à-vis huge fund allocations.

4. The interventionist institutions are but means of elite private enrichment to the continued suffering of the Niger Delta masses.

5. If there were transparency and accountability in the management of Niger Delta affairs by the institutional officials of the MNDA, especially the NDDC, the region would have had multiple and qualitative infrastructure and human capacity developments.

\section{Conclusion}

The beauty of social sciences is objectivity in the observation and analysis of social realities. This paper was inspired by the need to examine the activities of the afore-mentioned interventionist institutions of the Nigerian state, to the high need to develop the Niger Delta region. While this paper does not claim the first attempt at studying the sensitive issue of the Niger Delta region of Nigeria, 
the detailed examination of the interventionist bodies is a clear difference.

The methodology of documentary details and content analysis of secondary data, gave the study a navigating access to a wide range of available sources on the internet, hard copy material among others. These all were assistant in the historic trace and collection of details, revealing the unjustifiable elites' acts of fund misappropriation. Marxist Instrumentalist theoretical base of this paper, further helped to lay bare the root cause of the sustainable development deficit of the Niger Delta irrespective of the huge budgetary allocations and assistances from non-governmental bodies.

\section{Recommendations}

Based on the detailed observations of this paper, the way forward from the currently pitiable status quo of poor development of the Niger Delta can begin from the enumerations below:

1. Federal government of Nigeria should ensure that the officials of the interventionist bodies are not appointed on political compensatory basis; but based on objective assessment and character transparency.

2. Impact assessment should be carried out on any given fund while monitoring and oversight should not be sacrificed.

3. Stiffer penalty should be carried out against corrupt officials of the interventionist institutions, based on trial and conviction.

4. Federal government should increase programs based on human capacity building, education and environmental protection.

5. Institutional rules and regulations should be strengthened to ensure that individuals of the interventionist institutions in the Niger Delta do not grow stronger than the institutions.

6. The track way to the Niger Delta issues should not exclude institutional reforms that can enable transparent and capable minds, within the target beneficiaries, to run the institutions set to 
implement the development plans of government in the Niger Delta. This will undo the alienation of the masses and the elitist high jacking of the institutions, and create an atmosphere of horizontal co-relation and proximity among the people.

\author{
Kingsley Ubiebi \& \\ Ikechukwu Stanley Ogbonna \\ Department of Political Science \\ University of Nigeria, Nsukka \\ Enugu State, Nigeria \\ ubikings1865@gmail.com \\ ogbonnaikechukwustan@gmail.com
}

\title{
References
}

Aborisade, S. (2019). Senate House move to probe NDDC Accounts. Saturday Punch, 2nd, November, 2019.

Adetoye D., Owoeye T. and Omilusi M. (2017) Fiscal Federalism and Intergovernmental Economic Relations in Nigeria: A Descent from Derivation to Deprivation. Unpublished research work.

Agwanwo, D. E. (2014). State policing and police efficiency in

Nigeria, Research on Humanities and Social Sciences, 4 (25), $165-173$

Ajagun, S.O. 2003. "The Significance of Culture on Human Development in Nigeria". International Journal of Governance and Development, Vol.1 No.20, September 2003, pp.107-116.

Angela, A.(2017) Towards Ending Conflict and Insecurity in the Niger Delta Region: A Collective Non-Violent Approach . African Journal on Conflict Resolution. Vol. 17, No 1 (2017) Retrieve from:

https://www.ajol.info/index.php/ajcr/article/view/160582.

1/11/2019. 2:48 AM 
Anugwam, E. E. (2005). Oil minorities and the politics of resource control in Nigeria, CODESRIA, 30 (4),87-120

Awofeso, O. (2017). Secessionist movements and the national question in Nigeria, IJRDO Journal of Social Science and Humanities Research, 2 (7), 35-55

Azaiki, S. (2003). Inequities in Nigerian Politics. Yenagoa: Treasure Communications Resource Limited

Babalola, D.(2014). The Underdevelopment of Nigeria's Niger Delta Region: Who is to Blame? Journal of Sustainable Development. 7(3).

Babalola, D. (2016). Fiscal federalism and economic development in Nigeria: The contending issues, Global Journal of Political Science and Administration,3 (2), 53-69

Chijioke, S. U, Innocent, E.O \& Emeh,I.E.J. (2012). Issues in Nigerian fiscal federalism: The Relationship between the principle of derivation and resource control, Kuwait Chapter of Arabian Journal of Business and Management Review, 1 (5), 54-72

Clark, E. V. (2016) The Politics of Oil in Nigeria: Transparency and Accountability for Contemporary Research 6(4).

Eghweree, O. C. (2014). 'Oil Politics' and Development in Nigeria. Journal of Energy Technologies and Policy. 4(12)

Ejobowah, J. B. (2000). Who Owns the Oil? The Politics of Ethnicity in the Niger Delta of Nigeria. Africa Today, 47(1), 29-47. http://dx.doi.org/10.1353/at.2000.0011

Elekwa, N.N., Mathew, B.F. \& Akume, A.T. (2011). Fiscal restructuring in Nigeria: A historical review, JORIND, 9(2), $413-428$

Emmanuel, A. (2017). Willink's Report, Niger Delta Region and the Nigerian State 50 Years After: Any Hope for the Minority? Retrieve 
from:https://www.researchgate.net/publication/315408911_W illink's_Report_Niger_Delta_Region...31/10/2019.8:05 PM

Frynas, G. J. (2001). Corporate and State Responses to Anti-Oil Protests in the Niger Delta. African Affairs, 100, 27-54. http://dx.doi.org/10.1093/afraf/100.398.27

IMF. (2003). Oil Revenue and Budgeting in Nigeria. Official Bulletin No 6.

Konie, G. (2003) "National Reconciliation." The Post, a Zambian Newspaper July 23.No.2471,

pp: 11.

Madubuike, S. C (2017). Ethnic conflicts: Social identity and resource control agitations in the

Niger Delta National Conference (2014). Position of Ohaneze N'digbo: For and on

behalf of the Igbo-speaking people of Nigeria, Report of National Conference, Abuja

Manby, B. (1999), "The Price of Oil: Corporate Responsibility and Human Rights Violations in Nigeria's Oil Producing Communities", Human Rights Watch, New York. This work reported that water samples in the region have contained hydrocarbon levels as high as 680 times the level allowed in drinking water in the European Union.

Niger Delta Development Commission. Retrieved October 26, 2013, from www.nddc.gov.ng 26.10.2013

Obi, C. (2006). Youth and the Generational Dimensions to Struggles for Resource Control in the Niger Delta. Dakar, CODESRIA

Obiora, O. (2018). The Value of Diversity: Restructuring to save Nigeria. An Inaugural Lecture presented at University of Nigeria, Nsukka.

Oghator, E. \& Okoobo, R. (2000). Towards Sustainable Development in less Developed Countries: Foreign Assistance Revisited. The Nigerian Journal of Administrative Science. 
Ojakorotu, V. (2008). The internationalization of oil violence in the Niger Delta of Nigeria, Alternatives: Turkish Journal of International Relations, 7 (1), 92-118

Omoruyi Omo (2001) The politics of Oil: Who owns Oil, Nigeria, States or Communities? Retrieved from http://nigeriaworld.com/feature/publication/omoruyi/oil.html. Accessed 7th December, 2017

Onigu, O. (2009). The complexity behind Nigeria's Niger Delta Crisis. Born Black Magazine, 6th June, 2009.

Patrick, Akpan, L., Offiong, Mercy O., Obiageli, Orogbu L. and Ujunwa, Enemuo C., (2012). Conflict and Development of Oil Producing States: Empirical Reflections on Niger Delta Region of Nigeria. OIDA International Journal of Sustainable Development, Vol. 5, No. 5, pp. 111-118, 2012. Retrieved from https://ssrn.com/abstract=2185533. 30th October, 2017.

Paul, F.(2011) Securing Development and Peace in the Niger Delta: A social and Conflict Analysis for Change, Woodrow Wilson International Center for Scholars, Africa Program, One Woodrow Wilson Plaza, 1300 Pennsylvania Ave. Washington, DC 20004

Salisu, M. (2000). Corruption in Nigeria. Lancaster University Management School Working paper2000/006.The LUMS Working Papers series. Retrieved from: http://www.lums.co.uk/publications

UNDP. (2006). Niger Delta Human Development Report. Abuja: United Nations Development Programme.

Welch, C. E. (1995). The Ogoni and Self-Determination: Increasing Violence in Nigeria. Journal of Modern African Studies, Vol 3(4), pp 635-650 